\title{
Sleep Disorders and Genes
}

Eric Murillo-Rodríguez ${ }^{1,2,{ }^{*} \text {, Tetsuya Yamamoto }}{ }^{2,3}$, André Barciela Veras ${ }^{2,4}$, Nuno Barbosa Rocha ${ }^{2,5}$, Diogo Telles-Correira ${ }^{2,6}$, Sérgio Machado 2, 7,8, 9 , Diogo Monteiro ${ }^{2,10}$, Henning Budde ${ }^{2,11,12,13}$, and Pablo Torterolo ${ }^{2,14, *}$

${ }^{1}$ Laboratorio de Neurociencias Moleculares e Integrativas Escuela de Medicina, División Ciencias de la Salud Universidad Anáhuac Mayab. Mérida, Yucatán. México

${ }^{2}$ Intercontinental Neuroscience Research Group

${ }^{3}$ Graduate School of Technology, Industrial and Social Sciences

Tokushima University. Tokushima, Japan

${ }^{4}$ Universidade Catolica Dom Bosco. Campo Grande, Mato Grosso do Sul. Brazil

${ }^{5}$ Health School, Polytechnic Institute of Porto. Porto, Portugal

${ }^{6}$ University of Lisbon. Faculty of Medicine. Lisbon, Portugal

${ }^{7}$ Laboratory of Panic and Respiration, Institute of Psychiatry

Federal University of Rio de Janeiro. Rio de Janeiro, Brazil

${ }^{8}$ Salgado de Oliveira University. Rio de Janeiro, Brazil

${ }^{9}$ Physical Activity Neuroscience Laboratory, Physical Activity Sciences

Postgraduate Program-Salgado de Oliveira University (UNIVERSO)

Rio de Janeiro, Brazil

${ }^{10}$ Sport Science School of Rio Maior. Instituto Politécnico de Santarém Santarém, Portugal

${ }^{11}$ Faculty of Human Sciences, Medical School Hamburg. Hamburg, Germany 
${ }^{12}$ Physical Activity, Physical Education, Health and Sport Research Centre

(PAPESH), Sports Science Department, School of Science and Engineering

Reykjavik University. Reykjavik, Iceland

${ }^{13}$ Lithuanian Sports University. Kaunas, Lithuania

${ }^{14}$ Laboratorio de Neurobiología del Sueño. Depto. de Fisiología

Facultad de Medicina, Universidad de la República

Montevideo, Uruguay

\section{$\S$ Corresponding authors:}

Eric Murillo-Rodríguez, PhD.

Laboratorio de Neurociencias Moleculares e Integrativas

Escuela de Medicina, División Ciencias de la Salud. Universidad Anáhuac Mayab

Carretera Mérida-Progreso Km. 15.5; A.P. 96 Cordemex C.P. 97310

Mérida, Yucatán. México

Tel + $52(999)$ 942-4800 Ext. 664

Email: eric.murillo@anahuac.mx

Pablo Torterolo, MD, PhD.

Laboratorio de Neurobiología del Sueño. Depto. de Fisiología

Facultad de Medicina, Universidad de la República. Montevideo, Uruguay

Av. Gral. Flores 2125-1800 Montevideo, Uruguay

Tel + (5982) 9243414-3234

Email: ptortero@fmed.edu.uy 


\section{Abstract}

The sleep-wake cycle is a neurobiological phenomenon that shows intervals of activity alternating with restfulness that appears with a periodicity approximating the 24h day-night cycle. The sleep-wake cycle is under the control of diverse neuroanatomical and neurochemical systems, including monoaminergic, cholinergic, adenosinergic among many other systems. In addition, neuroanatomical

centers linked to sleep promotion, such as hypothalamus, project to the cerebral cortex, subcortical relays and brainstem. In addition, the sleep-wake cycle has been associated to aberrant features known as sleep disorders. Here, we will discuss the role of specific gene expression on sleep disturbances. Given the expansion of the knowledge in the sleep-wake cycle area, it is indeed ambitious to describe all the genetics involved in the sleep modulation. However, in this chapter we reviewed the current understanding of the sleep disorders and gene expression.

Keywords: CRISPR-Cas9; gene; insomnia; narcolepsy; restless legs syndrome; sleep-wake cycle. 


\section{Introduction}

Diverse neurobiological elements such as neurochemical, neuroanatomical, and genetic modulate the sleep-wake cycle. In addition, it has been described the link between gene expression and sleep disturbances. Among the most frequent, sleep alterations are insomnia and excessive daytime sleepiness. However, there are additional members of the sleep disturbance such as obstructive sleep apnea, narcolepsy, advanced sleep phase syndrome, restless legs syndrome, among others. Importantly, current evidence has demonstrated the genetic basis of multiple sleep disorders. Thus, it is likely that genetic phenomena contribute to the control of the sleep-wake cycle. Moreover, new therapeutical approaches aimed to manage sleep disorders should consider the genetics influence in the onset of pathologies related to sleep.

\section{The sleep-wake cycle: An Overview}

In humans, mammals and birds, three behavioral states can be readily distinguished: wakefulness (W), slow wave sleep (SWS) and rapid eye movement sleep (REMS). Polysomnography is the basic tool used to differentiate these states (Figure 1). It consists of the simultaneous recording of various physiological parameters such as the electroencephalogram (EEG), the electromyogram (EMG) and eye movements.

\section{PLEASE INSERT FIGURE 1 ABOVE HERE}




\section{Wakefulness}

During $\mathrm{W}$, there is an optimal interaction with the environment that allows the development of various behaviors necessary for survival. In humans, W is accompanied by awareness (consciousness) of the environment and internally generated stimuli such as hunger and thirst. The EEG recording of $W$ is defined by the presence of high frequency (above $15 \mathrm{~Hz}$ ) and low amplitude oscillations determined by the activity of thalamic and cortical neurons. In spite of this, during relaxed $\mathrm{W}$ with the eyes closed, regular alpha $(8-12 \mathrm{~Hz})$ activity predominates in the occipital region.

W-promoting neuronal networks, known as activating systems, are located in the reticular formation of the upper brainstem, postero-lateral hypothalamus and basal forebrain (1). These neurons are critical for the generation and maintenance of W; lesion of these areas generates a deficit in the maintenance of $\mathrm{W}$, including comma (2). It is also important to note that Narcolepsy, a paradigmatic hypersomnia, occurs because of a degeneration of neurons of the postero-lateral region of the hypothalamus that synthesize and utilize the neuropeptides hypocretin 1 and 2 (also called orexin A and B) as neuromodulators. The hypocretinergic neurons

promote $\mathrm{W}$, and are part of the activating system $(3,4)$. Neurons that constitute the activating system inhibit SWS promoting neuronal networks (see below). In fact, waking and SWS promoting neuronal networks have reciprocal inhibition between them (1). 
Slow wave sleep

During sleep, there is a marked decrease in the interaction with the environment, an increase of the threshold for the reaction to external stimuli, and a decrease in somatomotor activity. Furthermore, animals adopt a distinctive position to conserve heat.

In healthy adults, the transition from W to sleep is into SWS sleep. In humans, three SWS phases are distinguished according to the depth of the state: S1, S2 and S3. From W, normal adults enter in S1 or light SWS. This transitional state present low-voltage, mixed frequency waves $(2-7 \mathrm{~Hz}$ range) in the EEG. The S2 is characterized by the presence of sleep spindles and K-complexes in the EEG. Sleep spindles are "spindle-like" bursts of oscillatory activity of $11-15 \mathrm{~Hz}$ with a duration of $0.5-2$ seconds; the intervals between sleep spindles in human subjects are of 3 to 5 seconds (5). These events are generated by the interplay of the reticular thalamic nucleus with others thalamic nuclei. K-complex consists of a brief negative sharp high-voltage peak (usually greater than $100 \mu \mathrm{V}$ ), followed by a slower positive complex and final negative peak. K-complexes are often associated with sleep spindles. The S2 account for approximately $50 \%$ of the total sleep time during the night (6). The S3 is characterized by low frequency $(0.5$ to $4 \mathrm{~Hz}$, delta band of frequencies) of high amplitude $(>75 \mu \mathrm{V})$ waves in the EEG. S3 accounts for 12.5 to $20 \%$ of the total sleep time (6). 
Tonic parasympathetic activity increases during SWS determining characteristic changes in visceral activity, such as a pronounced decrease in heart rate (7). In the deeper stages of SWS, cognitive activity (i.e., dreams) is minimal (8-10). In the preoptic area of the hypothalamus are the main SWS promoting neuronal networks. Most of these neurons are GABAergic and inhibits the activating systems in order to generate SWS (11). In fact, pioneer studies by Von Economo showed that lesions of this area generates a severe insomnia (12).

\section{REM sleep}

REMS occurs periodically, and in normal adults is always preceded by SWS. REMS is a deep sleep stage although the EEG is similar to that of W (high frequency and low amplitude oscillations); hence, it is also called "paradoxical" sleep. REMS is also distinguished by fast, saccadic rapid eye movements and muscle atonia as evidenced in the EMG channel. Muscle atonia is produced mainly by postsynaptic hyperpolarization of the spinal and brainstem motoneurons (13). This REMS atonia is absent or reduced in REMS behavioral disorder, a parasomnia characterized by patients acting out their dreams (14). Phasic changes in autonomic activity, that generates irregular visceral activity (such as increases and decreases in blood pressure), is also associated with REMS (15). This state is also characterized by a lack of homeostatic control of body temperature (16). 
Cognitive activities not only occur during W. Dreams, which occur more prominently during REMS (8-10), are considered a special kind of cognitive activity or proto-consciousness (19). REM sleep dreams are characterized by their vividness, single-mindedness, bizarreness and loss of voluntary control over the plot. Attention is unstable and rigidly focused, facts and reality are not checked, violation of physical laws and bizarreness are passively accepted, contextual congruence is distorted and time is altered (18-20).

Dreams and psychosis, share important characteristics such as internal perceptions independent of external stimulation with a general lack of criticism. In addition, REMS shares neurophysiological, and neurochemical characteristics with psychosis; because of this fact, it is considered a natural model of this condition (21-23).

REMS occupies $20-25 \%$ of total sleep in human adults, and appears about $\sim 90$ minutes after sleep onset (REMS latency) (24). A shortened REMS latency (the interval between the sleep onset and the appearance of the first REMS episode) is a biological marker of primary depression (25). It is also considered to be a clinically significant pathological feature in narcolepsy (26).

Sleep during the night shows four to five SWS-REMS cycles (the period from the sleep onset to the end of first REMS episode or the period from the end of a REMS episode to the subsequent REMS episode). The average length of human sleep cycles is about 90 to 110 minutes (27). 
Neuronal networks of the ponto-mesencephalic reticular formation are necessary and sufficient for REMS generation (28). These neuronal networks are also involved in the control of W (constitute the ascending reticular activating system). However, the activity of these neurons differs between W and REMS. More recent, neurons of the lateral hypothalamus and incerto-hypothalamic area that synthesize and employ the neuropeptide melanin-concentrating hormone $(\mathrm{MCH})$ as neuromodulator, has been involved both in the generation of SWS and REMS (29, 30). In addition, malfunctioning of the MCHergic system may be involved in the pathophysiology of depression (31). $\mathrm{MCH}$ antagonists are considered promising antidepressive and anxiolytic drugs (32).

\section{Circadian and homeostatic regulation of sleep}

The physiological transition between $\mathrm{W}$ and sleep is regulated by a circadian and a homeostatic component (33). Like all circadian rhythms, sleep and W are regulated by commands from the suprachiasmatic nucleus (SCN) of the hypothalamus. The $\mathrm{SCN}$ receives photic information directly from the retina, and regulates the activity of both the hypnogenic and activating systems (34). Furthermore, through indirect modulation of the sympathetic system, the SCN regulates the release of melatonin from the pineal gland during the night (35). Melatonin has a weak sleep-promoting effect.

The homeostatic component also regulates the sleep-wake cycle; i.e., prolonged $\mathrm{W}$ facilitates the generation of sleep. Different lines of research have shown that sleep-promoting substances, including adenosine, are released and accumulated 
during $W(36,37)$. Adenosine promotes sleep by inhibiting the activating systems and stimulating SWS promoting systems. Of interest, caffeine promotes $\mathrm{W}$ by blocking the receptors for adenosine (38).

Sleep is also deeply modified with age. In the newborn transition from W to sleep is often accomplishes through REMS (called active sleep in newborns). The sleep cycle (alternation of SWS-REMS) period in newborn is of $50-60$ minutes and the circadian organization is not present $(39,40)$. In addition, a shortening in sleep duration, mainly related to the reduction in S3 and REMS, is associated with aging (27).

\section{Basis of Gene Expression}

It is widely accepted that genes are the database contained inside the nucleus of all cells, and are responsible of physical and functional characteristics of subjects. Since every gene contains a particular set of molecular instructions for codifying a specific protein, this process is known as gene expression (41, 42). Remarkably, there is a natural variation in human gene expression. Every single person possesses two copies of each gene (one comes from each parent) and in turn, each human being has its own genetic information, which was inherited from its progenitor. Thus, the physical characteristics, physiology and even predisposition to certain pathologic conditions are also coded in genes. However, it is worthy to mention that not all genes are active at all times. It seems that some genes respond only when they interact with the environment, remaining active only for a limited time window (43). Since some genes have been linked with sleep disorders, 
this review provides a broad understanding of the present knowledge regarding the sleep disorders and genes expression.

\section{Gene Expression in pathological conditions}

As mentioned previously, genes contain molecular instructions for codifying a specific protein, including some aberrant features. Clinically, we can interpret this molecular event as pathology. Most known cases of diseases-linked to gene expression are cancer, diabetes, neurodegenerative disorders, obesity and many others (44). For example, in cancer, it has been reported that the protein named Semaphorin-3E (Sema3E) shows an overexpression in human pancreatic cancer. In addition, Sema3E has been suggested as a contributor to tumor progression and metastasis, since it has been detected in pancreatic cancer cells inducing cellular proliferation. In opposition, experimental Sema3E knockout animals, displays a suppression of cancer cellular proliferation and a reduction tumors' size (45). Another example of the role of nuclear elements related to diseases is the mRNA. In this regard, osteoporosis is a common disease in aging population, and it has been suggested that this disturbance is related to the normal decalcification rate. The origin of this health problem has been associated to causes such as deficiency in vitamin D, calcium, addiction to alcohol, as well as gene expression. Recent evidence has demonstrated that circulating mRNAs levels in postmenopausal subjects could be used as potential biomarkers for osteoporosis (46). Given the complex relationship between health disturbances and gene expression, it is not a surprise the extensive of this field. 


\section{Sleep Disorders linked to Gene Expression}

Insomnia

In previous chapters of the current book, several sleep disturbances have been described. Thus, we will avoid redundancy in information. In the case of insomnia, this sleep disturbance is characterized by the difficulty to initiate or maintain sleep. Regarding the genetic basis of insomnia, several pieces of evidence have reported the critical role of multiple circadian genes, such as CLOCK, PER, Timeless, etc., in subjects that present insomnia as well as mood disorders (47-53). Additional examples of relationship between specific gene expression and insomnia is the data reported about genes that are related to the duration of a precise state of vigilance. In this case, Per2 and Per3 activity have shown higher patters of expression and insomnia $(51,52)$.

Additional genes have been added to the list of genes related to insomnia. For example, adenosine, GABA, serotonin transporter polymorphic region (5-HTTLPR), and orexin/hypocretin show higher pattern of expression in insomniac conditions (47). To further complicate the scenario, several reports have suggested the

involvement of additional wake-related neurotransmitter systems, including dopaminergic system genes (i.e., dopamine transporter 1 (DAT1), catecholamineO-methyltransferase $(C O M T)$, dopamine receptor D4 $(D R D 4)(47,54))$. Current 
genome-wide association studies (GWAS) have reported novel genes that seems to be associated to insomnia, such as ABCC9 gene (rs11046209) (54-57).

\section{Obstructive Sleep Apnea}

The clinical feature of repeated cessation or attenuation of breathing (named "apneas" and "hypopneas", respectively) during sleep is known as obstructive sleep apnea (OSA). This sleep disorder is also linked with several health dysfunctions such as hypertension, obesity, heart failure, among others (58). The first-line treatment given to subjects that present OSA comprises the use of an equipment that provides air pressure known as continuous positive airway pressure or $\operatorname{CPAP}(58,59)$.

The molecular mechanisms underlying OSA remain unclear. However, there is evidence that suggests the involvement of genes. In this regard, GWAS in 12,558 Hispanic subjects found two novel loci at genome level with significance for apneahypopnea index (60). In addition, it has been proposed that genes related with inflammation might be linked to OSA. Thus, inflammatory factors, including IL-6, IL8, and TNF- $\alpha$, have been found highly expressed in patients with OSA $(61,62)$. Additional gene candidates for OSA promotion are the 5-hydroxytryptamine receptor 2A (5-HTR2A) and interleukin-6 (IL-6) $(63,64)$.

\section{Narcolepsy}


The major symptoms of narcolepsy comprise excessive daytime sleepiness and cataplexy. Regarding the genetic basis of this sleep disorder, it has been suggested that the human leukocyte antigen $(H L A)$-DRB1 $\times 15: 01-D Q B 1 \times 06: 02$ haplotype seems to be linked with narcolepsy (65-67). In addition, GWAS in 525,196 single nucleotide polymorphisms (SNPs) have been identified outside of the HLA region and associated to narcolepsy (68). Recent studies have shown that SNP in the promoter region of chemokine (C-C motif) receptor 1 (CCR1) is also linked to narcolepsy.

\section{Advanced Sleep Phase Syndrome}

Earth's rotation once in about $24 \mathrm{~h}$ with respect to the Sun, but once every $23 \mathrm{~h}$, $56 \mathrm{~min}$, and $4 \mathrm{~s}$ approximately with respect to the stars. Thus, this cycle named circadian rhythm has established a remarkable influence in neurobiological activity of several species, including humans. In this regard, the circadian rhythm has also evidenced the existence of pathological circadian-related issues, such as sleep disturbances (70-74). For example, the advance sleep phase syndrome is characterized by subjects complaint of early evening bedtimes or early morning awakenings. In this case, this abnormal feature of sleep onset is named advance sleep phase syndrome. This sleep disturbance is evident when social constraints force the patients to late bedtimes $(75,76)$.

The sleep control under the influence of the circadian rhythm responds to specific genes. In this regard, approximately $10 \%$ of the population are homozygous for the 5-repeat allele (PER3(5/5)) of a variable number tandem repeated polymorphism in 
the clock gene named Per-3. Importantly, PER3(5/5) has been linked to morning preference, while homozygosity for the four-repeat allele $(P E R 3(4 / 4))$ seems to be associated with evening preference (77).

Genetic studies have contributed to the understanding of the molecular basis of circadian rhythms and associated sleep disorders. In this regard, more than 20 genes have been characterized, including PER 1,2, and 3, the cryptochrome genes 1 and 2, and brain and muscle arnt-like protein-1 (Bmal1/Aryl hydrocarbon receptor nuclear translocator- like [ARNTL1], $(78,79))$.

It is worthy to mention that diurnal preference seems also to be the result of activation of specific genes. For example, diurnal preference and a polymorphism in Per-3 or polymorphism in aryl hydrocarbon receptor nuclear translocatorlike 2 (ARNTL2) has been described (80). In addition, significant gene-associated loci with morningness has been suggested (81). Taking together, we can conclude that genes with circadian expression play a key role in modulation of sleep onset as well as in circadian-related sleep disturbances (82-86).

\section{Restless Legs Syndrome}

The restless legs syndrome is a pathological condition characterized by the urge to move the legs during $\mathrm{W}$, and is associated with periodic leg movements during sleep.

The substantia nigra, a critical brain area for modulating movement, is composed of dopaminergic neurons that project to the striatum; low iron concentration within 
this area, seems to be involved in the genesis of this sleep disorder $(87,88)$. Although significant advances have been achieved in the understanding of the restless legs syndrome, the genetics of this sleep disorder are still unknown. Current evidence suggests that genes such as IL- $\beta$ or BTBD9 participate in the onset of the motor disorder $(89,90)$. In addition, since this sleep disturbance has familial aggregation, GWAS studies have identified single nucleotide polymorphisms linked to the restless legs syndrome, including SNP at loci MEIS1 (91-93). Indeed, more research is needed to clarify the role of genes that are participating in the onset of the restless legs syndrome (87-94).

\section{Could we edit genes related to sleep disorders? The case of CRISPR-Cas9}

Recently, it has been reported the gene editing technique known as Clustered Regularly Interspaced Short Palindromic Repeats (CRISPR). Briefly, CRISPR uses a guide RNA to send biological "scissors" -usually the CRISPR-associated protein, Cas9- to a precise spot to cut and make a substitution in the genome. As one can imagine, CRISPR-Cas9 provides the technology to manipulate genomic sequences, focusing in human diseases, such as HIV and cancer (95-99). Moreover, CRISPR-Cas9- might be also considered to editing genes in sleep disorders, such as insomnia, OSA, narcolepsy, advanced sleep phase syndrome, or restless legs syndrome (100,101; Figure 2). Indeed, it is needed to explore of the use of CRISPR-Cas9 in animal models of sleep disorders before to consider it a "bench-to-bedside" approach $(102,103)$. 


\section{Conclusions}

The sleep-wake cycle is a physiological phenomenon that displays, as many other functions, aberrant features that have been characterized as sleep disturbances. Within the family of sleep disorders, insomnia, OSA, narcolepsy, advanced sleep phase syndrome and restless legs syndrome, are some of the unhealthy features of sleep. Research aimed to understand the origin of sleep disturbances have included the studies of gene expression linked to those sleep pathologies. In this regard, identifying the genes related to sleep disturbances have made significant achievements in the sleep medicine area. Currently, the modern molecular technique CRISPR-Cas9 might be considered to editing genes and its putative use is highly tempting to regulate or eliminate the sleep disturbances. Indeed, further studies are required to describe the potential use of CRISPR-Cas9 in edition of genes related to sleep disorders.

\section{Acknowledgments}

This work was supported by The University of California Institute for Mexico and the United States (UC MEXUS) and Consejo Nacional de Ciencia y Tecnología (CONACyT; Grant\# CN-17-19) and Escuela de Medicina, Universidad Anáhuac Mayab (Grant: PresInvEMR2017) given to E. M-R.

\section{References}

1. Torterolo, P. \& Vanini, G. (2010) Nuevos conceptos sobre la generación y el mantenimiento de la vigilia. Revista de Neurología., 50, 747-758. 
2. Posner, J.; Saper, C.B., Schiff, N.D. \& Plum, F. (2007) The diagnosis of stupor and coma. $4^{\text {th }}$ Edition, Oxford University Press, New York.

3. Torterolo, P. \& Chase, M.H. (2014) The hypocretins (orexins) mediate the "phasic" components of REM sleep: a new hypothesis. Sleep Science, 7, 1929.

4. Torterolo, P., Monti, J. \& Pandi-Perumal, S.R. (2015) Role of orexin on sleep: interactions with other neurotransmitter systems. In Sakurai, T., Monti, J., Pandi-Perumal, S.R. (eds) Orexin and Sleep. Springer, pp. 181-202.

5. Evans, B.M. \& Richardson, N.E. (1995) Demonstration of a 3-5s periodicity between the spindle bursts in NREM sleep in man. J Sleep Res, 4, 196-197.

6. Keenan, S. \& Hirshkowitz, M. (2011) Monitoring and staging human sleep. In Kryger, M.H., Roth, T., Dement, W.C. (eds) Principles and practices of sleep medicine. Elsevier-Saunders, Philadelphia, pp. 1602-1609.

7. Brando, V., Castro-Zaballa, S., Falconi, A., Torterolo, P. \& Migliaro, E.R. (2014) Statistical, spectral and non-linear analysis of the heart rate variability during wakefulness and sleep. Arch Ital Biol, 152, 32-46.

8. Dement, W. \& Kleitman, N. (1957) The relation of eye movements during sleep to dream activity: an objective method for the study of dreaming. $J$ Exp Psychol, 53, 339-346.

9. Pace-Schott, E. (2011) The neurobiology of dreaming. In Kryger, M.H., Roth, T., Dement, W.C. (eds) Principles and practices of sleep medicine. ElsevierSaunders, Philadelphia, pp. 563-575. 
10. Siclari, F., Baird, B., Perogamvros, L., Bernardi, G., LaRocque, J.J., Riedner, B., Boly, M., Postle, B.R. \& Tononi, G. (2017) The neural correlates of dreaming. Nat Neurosci, 20, 872-878.

11.Scammell, T.E., Arrigoni, E. \& Lipton, J.O. (2017) Neural Circuitry of Wakefulness and Sleep. Neuron, 93, 747-765.

12. Von Economo, C. (1930) Sleep as a problem of localization. J Nerv Ment Dis, 71, 249-259.

13. Chase, M.H. (2013) Motor control during sleep and wakefulness: clarifying controversies and resolving paradoxes. Sleep Med Rev, 17, 299-312.

14. Mahowald, M.W. \& Schneck, C. (2011) REM sleep parasomnias. In Kryger, M.H., Roth, T., Dement, W.C. (eds) Principles and practices of sleep medicine. Elsevier-Saunders, Philadelphia, pp. 1083-1097.

15. Amici, R., Cerri, M. \& Parmeggiani, P.L. (2013) Overview of Physiological Processes During Sleep Encyclopedia of Sleep. Elsevier.

16. Parmeggiani, P.L. (2003) Thermoregulation and sleep. Front Biosci, 8, s557567.

17. Hobson, J.A. (1997) Dreaming as delirium: a mental status analysis of our nightly madness. Semin Neurol, 17, 121-128.

18. Rechtschaffen, A. (1978) The single-mindedness and isolation of dreams. Sleep, 1, 97-109.

19. Hobson, J.A. (2009) REM sleep and dreaming: towards a theory of protoconsciousness. Nat Rev Neurosci, 10, 803-813. 
20. Nir, Y. \& Tononi, G. (2010) Dreaming and the brain: from phenomenology to neurophysiology. Trends Cogn Sci, 14, 88-100.

21. Naiman R. (2017) Dreamless: the silent epidemic of REM sleep loss. Ann N Y Acad Sci. 1406(1):77-85.

22. Gottesmann, C. (2006) The dreaming sleep stage: a new neurobiological model of schizophrenia? Neuroscience, 140, 1105-1115.

23. Gottesmann, C. \& Gottesman, I. (2007) The neurobiological characteristics of rapid eye movement (REM) sleep are candidate endophenotypes of depression, schizophrenia, mental retardation and dementia. Prog Neurobiol, 81, 237-250.

24. Keenan, S. \& Hirshkowitz, M. (2011) Monitoring and staging human sleep. In Kryger, M.H., Roth, T., Dement, W.C. (eds) Principles and practices of sleep medicine. Elsevier-Saunders, Philadelphia, pp. 1602-1609.

25. Palagini, L., Baglioni, C., Ciapparelli, A., Gemignani, A. \& Riemann, D. (2013) REM sleep dysregulation in depression: State of the art. Sleep Med Rev. 17(5):377-90

26. Guilleminault, C. \& Fromherz, S. (2011) Narcolepsy: Diagnosis and Management. In Kryger, M.H., Roth, T., Dement, W.C. (eds) Principles and practices of sleep medicine. Saunders, Philadelphia, pp. 957-968.

27. Carskadon, M.A. \& Dement, W. (2011) Normal human sleep: an overview. In Kryger, M.H., Roth, T., Dement, W. (eds) Principles and practices of sleep medicine. Elsevier-Saunders, Philadelphia, pp. 16-26. 
28. Siegel, J.M. (2011) REM Sleep. In Kryger, M.H., Roth, T., Dement, W.C. (eds) Principles and practices of sleep medicine. Elsevier-Saunders, Philadelphia, pp. 92-111.

29. Torterolo, P., Lagos, P. \& Monti, J.M. (2011) Melanin-concentrating hormone (MCH): a new sleep factor? Frontiers in Neurology, 2, 1-12.

30. Monti, J.M., Torterolo, P. \& Lagos, P. (2013) Melanin-concentrating hormone control of sleep-wake behavior. Sleep Medicine Reviews, 17, 293-298.

31. Torterolo, P., Scorza, C., Lagos, P., Urbanavicius, J., Benedetto, L., Pascovich, C., Lopez-Hill, X., Chase, M.H. \& Monti, J.M. (2015) MelaninConcentrating Hormone $(\mathrm{MCH})$ : Role in REM Sleep and Depression. Front Neurosci, 9, 475.

32. Chaki, S. (2018) MCH Receptor 1 Antagonists: Antidepressant/Anxiolytic Potential in Animal Models. In Pandi Perumal, S.R., Torterolo, P., Monti, J. (eds) Melanin-concentrating Hormone and Sleep. Springer, Switzerland, pp. 207-225.

33. Borbely, A.A. (1982) A two process model of sleep regulation. Hum Neurobiol, 1, 195-204.

34. Mistlberger, R.E. (2005) Circadian regulation of sleep in mammals: role of the suprachiasmatic nucleus. Brain Res Brain Res Rev, 49, 429-454.

35. Pandi-Perumal, S.R., Trakht, I., Srinivasan, V., Spence, D.W., Maestroni, G.J., Zisapel, N. \& Cardinali, D.P. (2008) Physiological effects of melatonin: role of melatonin receptors and signal transduction pathways. Prog Neurobiol, 85, 335-353. 
36. Basheer, R., Strecker, R.E., Thakkar, M.M. \& McCarley, R.W. (2004) Adenosine and sleep-wake regulation. Prog Neurobiol, 73, 379-396.

37. Huang, Z.L., Urade, Y. \& Hayaishi, O. (2011) The role of adenosine in the regulation of sleep. Curr Top Med Chem, 11, 1047-1057.

38. Nishino, S. \& Mignot, E. (2005) Wake-promoting medications: basic mechanisms and pharmacology. In Kryger, M.H., Roth, T., Dement, W.C. (eds) Principles and practices of sleep medicine. Elsevier-Saunders, Philadelphia, pp. 468-483.

39. Roffwarg, H.P., Muzio, J.N. \& Dement, W.C. (1966) Ontogenetic development of the human sleep-dream cycle. Science, 152, 604-619.

40. Peirano, P.D. \& Algarin, C.R. (2007) Sleep in brain development. Biol Res, 40, 471-478.

41. Chatterjee S, Ahituv N. Gene regulatory elements, major drivers of human disease. Annu Rev Genomics Hum Genet. 2017; 18: 45-63.

42. Petit F, Sears KE, Ahituv N. Limb development: a paradigm of gene regulation. Nat Rev Genet. 2017; 18:245-58.

43. Lusk CP, King MC. The nucleus: keeping it together by keeping it apart. Curr Opin Cell Biol. 2017; 44: 44-50.

44. Barbagallo I, Li Volti G, Galvano F, Tettamanti G, Pluchinotta FR, Bergante S, Vanella L. Diabetic human adipose tissue derived mesenchymal stem cells fail to differentiate in functional adipocytes. Exp Biol Med. 2016; 242:1079-85.

45. Yong LK, Lai S, Liang Z, Poteet E, Chen F, van Buren G, Fisher W, Mo Q, Chen C, Yao Q. Overexpression of Semaphorin-3E enhances pancreatic 
cancer cell growth and associates with poor patient survival. Oncotarget. 2016; 7: 87431-48.

46. Chen J, Li K, Pang Q, Yang C, Zhang H, Wu F, Cao H, Liu H, Wan Y, Xia W, Wang J, Dai Z, Li Y. Identification of suitable reference gene and biomarkers of serum miRNAs for osteoporosis. Sci Rep. 2016; 6: 36347.

47. Lind MJ, Gehrman PR. Genetic pathways to insomnia. Brain Sci. 2010; 6: E64.

48. Serretti A, Benedetti F, Mandelli L, Lorenzi C, Pirovano A, Colombo C, Smeraldi E. Genetic dissection of psychopathological symptoms: insomnia in mood disorders and CLOCK gene polymorphism. Am J Med Gen. 2010; 121B: 35-8.

49. Serretti A, Gaspar-Barba E, Calati R, Cruz-Fuentes CS, Gomez-Sanchez A, Perez-Molina A, De Ronchi D. 3111T/C clock gene polymorphism is not associated with sleep disturbances in untreated depressed patients. Chronobiol Int. 2003; 27: 265-77.

50. Utge SJ, Soronen P, Loukola A, Kronholm E, Ollila HM, Pirkola S, PorkkaHeiskanen T, Partonen T, Paunio T. Systematic analysis of circadian genes in a population-based sample reveals association of TIMELESS with depression and sleep disturbance. PLoS One. 2010; 5: e9259.

51.Brower KJ, Wojnar M, Sliwerska E, Armitage R, Burmeister M. PER3 polymorphism and insomnia severity in alcohol dependence. Sleep. 2012; 35: $571-7$. 
52. Li J, Huang C, Lan Y, Wang Y. A cross-sectional study on the relationships among the polymorphism of period2 gene, work stress, and insomnia. Sleep Breath. 2015; 19: 1399-406.

53. Mendlewicz J. Disruption of the circadian timing systems: molecular mechanisms in mood disorders. CNS Drugs. 2009; 23: 15-26.

54.Ban HJ, Kim SC, Seo J, Kang HB, Choi JK. Genetic and metabolic characterization of insomnia. PLoS ONE. 2011; 6: e18455.

55. Byrne EM, Gehrman PR, Medland SE, Nyholt DR, Heath AC, Madden PA, Hickie IB, Van Duijn CM, Henders AK, Montgomery GW, Martin NG, Wray NR, Chronogen Consortium. A genome-wide association study of sleep habits and insomnia. Am J Med Gen. 2013; 162: 439-51.

56. Ollila HM, Kettunen J, Pietiläinen O, Aho V, Silander K, Kronholm E, Perola M, Lahti J, Räikkönen K, Widen E, Palotie A, Eriksson JG, Partonen T, Kaprio J, Salomaa V, Raitakari O, Lehtimäki T, Sallinen M, Härmä M, Porkka-Heiskanen T, Paunio T. Genome-wide association study of sleep duration in the Finnish population. J Sleep Res. 2016; 23: 609-18.

57. Spada J, Scholz M, Kirsten H, Hensch T, Horn K, Jawinski P, Ulke C, Burkhardt R, Wirkner K, Loeffler M, Hegerl U, Sander C. Genome-wide association analysis of actigraphic sleep phenotypes in the LIFE Adult Study. J Sleep Res. 2016; 25: 690-701.

58. Subramani $Y$, Singh M, Wong J, Kushida CA, Malhotra A, Chung F. Understanding phenotypes of obstructive sleep apnea: applications in anesthesia, surgery, and perioperative medicine. Anesth Analg. 2017; 124: $179-91$. 
59. Patel N, Donahue C, Shenoy A, Patel A, El-Sherif N. Obstructive sleep apnea and arrhythmia: a systemic review. Int J Cardiol.2017; 228: 967-70.

60. Cade BE, Chen H, Stilp AM, Gleason KJ, Sofer T, Ancoli-Israel S, Arens R, Bell GI, Below JE, Bjonnes AC, Chun S, Conomos MP, Evans DS, Johnson WC, Frazier-Wood AC, Lane JM, Larkin EK, Loredo JS, Post WS, Ramos AR, Rice K, Rotter JI, Shah NA, Stone KL, Taylor KD, Thornton TA, Tranah GJ, Wang C, Zee PC, Hanis CL, Sunyaev SR, Patel SR, Laurie CC, Zhu X, Saxena R, Lin X, Redline S. Genetic associations with obstructive sleep apnea traits in Hispanic/Latino Americans. Am J Resp Crit Care Med. 2016; 194: 886-97.

61. Huang YS, Guilleminault C, Hwang M, Cheng C, Lin CH, Li HY, Lee LA. Inflammatory cytokines in pediatric obstructive sleep apnea. Med. 2016; 95: e4944.

62. Hirotsu C, Albuquerque RG, Nogueira H, Hachul H, Bittencourt L, Tufik S, Andersen ML. The relationship between sleep apnea, metabolic dysfunction and inflammation: the gender influence. Brain Behav Immun. 2017; 59: 211 8.

63. Wu W, Li Z, Tang T, Wu J, Liu F, Gu L. 5-HTR2A and IL-6 polymorphisms and obstructive sleep apnea-hypopnea syndrome. Biomed Rep. 2016; 4: 203-8.

64. de Lima FF, Mazzotti DR, Tufik S, Bittencourt L. The role inflammatory response genes in obstructive sleep apnea syndrome: a review. Sleep Breath. 2016; 20: 331-8. 
65. Dong XS, Ma SF, Cao CW, Li J, An P, Zhao L, Liu NY, Yan H, Hu QT, Mignot E, Strohl KP, Gao ZC, Zeng C, Han F. Hypocretin (orexin) neuropeptide precursor gene, HCRT, polymorphisms in early-onset narcolepsy with cataplexy. Sleep Med. 2013; 14: 482-7.

66. Han F, Lin L, Schormair B, Pizza F, Plazzi G, Ollila HM, Nevsimalova S, Jennum P, Knudsen S, Winkelmann J, Coquillard C, Babrzadeh F, Strom TM, Wang C, Mindrinos M, Fernandez Vina M, Mignot E. HLA DQB1*06:02 negative narcolepsy with hypocretin/orexin deficiency. Sleep. 2014; 37: $1601-8$.

67. Miyagawa T, Toyoda H, Hirataka A, Kanbayashi T, Imanishi A, Sagawa $Y$, Kotorii N, Kotorii T, Hashizume Y, Ogi K, Hiejima H, Kamei Y, Hida A, Miyamoto M, Imai M, Fujimura Y, Tamura Y, Ikegami A, Wada Y, Moriya S, Furuya H, Kato M, Omata N, Kojima H, Kashiwase K, Saji H, Khor SS, Yamasaki M, Wada Y, Ishigooka J, Kuroda K, Kume K, Chiba S, Yamada N, Okawa M, Hirata K, Uchimura N, Shimizu T, Inoue Y, Honda Y, Mishima K, Honda M, Tokunaga K. New susceptibility variants to narcolepsy identified in HLA class II region. Human Mol Gen. 2015; 24: 891-8.

68. Toyoda H, Miyagawa T, Koike A, Kanbayashi T, Imanishi A, Sagawa Y, Kotorii N, Kotorii T, Hashizume Y, Ogi K, Hiejima H, Kamei Y, Hida A, Miyamoto M, Imai M, Fujimura Y, Tamura Y, Ikegami A, Wada Y, Moriya S, Furuya H, Takeuchi M, Kirino Y, Meguro A, Remmers EF, Kawamura Y, Otowa T, Miyashita A, Kashiwase K, Khor SS, Yamasaki M, Kuwano R, Sasaki T, Ishigooka J, Kuroda K, Kume K, Chiba S, Yamada N, Okawa M, Hirata K, Mizuki N, Uchimura N, Shimizu T, Inoue Y, Honda Y, Mishima K, 
Honda M, Tokunaga K. A polymorphism in CCR1/CCR3 is associated with narcolepsy. Brain Behav Imm. 2015; 49: 148-55.

69. Tafti M, Lammers GJ, Dauvilliers Y, Overeem S, Mayer G, Nowak J, Pfister C, Dubois V, Eliaou JF, Eberhard HP, Liblau R, Wierzbicka A, Geisler P, Bassetti CL, Mathis J, Lecendreux M, Khatami R, Heinzer R, Haba-Rubio J, Feketeova E, Baumann CR, Kutalik Z, Tiercy JM. Narcolepsy-associated HLA class I alleles implicate cell-mediated cytotoxicity. Sleep. 2016; 39: 5817.

70. Johansson AS, Owe-Larsson B, Hetta J, Lundkvist GB. Altered circadian clock gene expression in patients with schizophrenia. Schizophrenia Res. 2016; 174: 17-23.

71. Luo W, Ma S, Yang Y, Zhang D, Zhang Q, Liu Y, Liu Z. TFEB regulates PER3 expression via glucose-dependent effects on CLOCK/BMAL1. Int J Bioch Cell Biol. 2016; 78: 31-42.

72. Panda S. Circadian physiology of metabolism. Science. 2016; 354: 1008-15

73.33. Riddle M, Mezias E, Foley D, LeSauter J, Silver R. Differential localization of PER1 and PER2 in the brain master circadian clock. Eur $\mathrm{J}$ Neurosci. 2016; 45: 1357-67.

74. Videnovic A, Willis GL. Circadian system-a novel diagnostic and therapeutic target in Parkinson's disease? Mov Dis. 2016; 31: 260-9.

75. Potter GD, Skene DJ, Arendt J, Cade JE, Grant PJ, Hardie LJ. Circadian rhythm and sleep disruption: causes, metabolic consequences, and countermeasures. Endocrin Rev. 2016; 37: 584-608. 
76. van Maanen A, Meijer AM, van der Heijden KB, Oort FJ. The effects of light therapy on sleep problems: a systematic review and meta-analysis. Sleep Med Rev. 2016; 29: 52-62.

77. Dijk DJ, Archer SN. PERIOD3, circadian phenotypes, and sleep homeostasis. Sleep Med Rev. 2010; 14: 151-60.

78. Nordgren A. Genes, body clocks and prevention of sleep problems. Med Health Care Phil. 2016; 19: 569-79.

79. Turek FW. Circadian clocks: not your grandfather's clock. Science. 2016; 354: 992-3.

80. Parsons MJ, Lester KJ, Barclay NL, Archer SN, Nolan PM, Eley TC, Gregory AM. Polymorphisms in the circadian expressed genes PER3 and ARNTL2 are associated with diurnal preference and GNB3 with sleep measures. Sleep Res. 2014; 23: 595-604.

81. Hu Y, Shmygelska A, Tran D, Eriksson N, Tung JY, Hinds DA. GWAS of 89,283 individuals identifies genetic variants associated with self-reporting of being a morning person. Nat Com. 2016; 7: 10448.

82. Amin N, Allebrandt KV, van der Spek A, Müller-Myhsok B, Hek K, TederLaving M, Hayward C, Esko T, van Mill JG, Mbarek H, Watson NF, Melville SA, Del Greco FM, Byrne EM, Oole E, Kolcic I, Chen TH, Evans DS, Coresh J, Vogelzangs N, Karjalainen J, Willemsen G, Gharib SA, Zgaga L, Mihailov E, Stone KL, Campbell H, Brouwer RW, Demirkan A, Isaacs A, Dogas Z, Marciante KD, Campbell S, Borovecki F, Luik AI, Li M, Hottenga JJ, Huffman JE, van den Hout MC, Cummings SR, Aulchenko YS, Gehrman PR, Uitterlinden AG, Wichmann HE, Müller-Nurasyid M, Fehrmann RS, 
Montgomery GW, Hofman A, Kao WH, Oostra BA, Wright AF, Vink JM, Wilson JF, Pramstaller PP, Hicks AA, Polasek O, Punjabi NM, Redline S, Psaty BM, Heath AC, Merrow M, Tranah GJ, Gottlieb DJ, Boomsma DI, Martin NG, Rudan I, Tiemeier H, van ljcken WF, Penninx BW, Metspalu A, Meitinger T, Franke L, Roenneberg T, van Duijn CM. Genetic variants in RBFOX3 are associated with sleep latency. Eur J Human Gen. 2016; 24: 1488-95.

83. Cade BE, Gottlieb DJ, Lauderdale DS, Bennett DA, Buchman AS, Buxbaum SG, De Jager PL, Evans DS, Fülöp T, Gharib SA, Johnson WC, Kim H, Larkin EK, Lee SK, Lim AS, Punjabi NM, Shin C, Stone KL, Tranah GJ, Weng J, Yaffe K, Zee PC, Patel SR, Zhu X, Redline S, Saxena R. Common variants in DRD2 are associated with sleep duration: the CARe consortium. Human Mol Gen. 2016; 25: 167-79.

84. Chang AM, Bjonnes AC, Aeschbach D. Circadian gene variants influence sleep and the sleep electroencephalogram in humans. Chronobio Int. 2016; 33: $561-73$.

85.Dall'Ara I, Ghirotto S, Ingusci S, Bagarolo G, Bertolucci C, Barbujani G. Demographic history and adaptation account for clock gene diversity in humans. Heredity. 2016; 117: 165-72.

86. Truong KK, Lam MT, Grandner MA, Sassoon CS, Malhotra A. Timing matters: circadian rhythm in sepsis, obstructive lung disease, obstructive sleep apnea, and cancer. Ann Am Thor Soc. 2016; 13: 1144-54.

87. Rizzo G, Li X, Galantucci S, Filippi M, Cho YW. Brain imaging and networks in restless legs syndrome. Sleep Med. 2016; 31: 39-48. 
88. Scherer JS, Combs SA, Brennan F. Sleep disorders, restless legs syndrome, and uremic pruritus: diagnosis and treatment of common symptoms in dialysis patients. Am J Kidney Dis. 2017; 69: 117-28.

89. Hennessy MD, Zak RS, Gay CL, Pullinger CR, Lee KA, Aouizerat BE. Polymorphisms of interleukin-1 Beta and interleukin-17Alpha genes are associated with restless legs syndrome. Biol Res Nurs. 2014; 16: 143-51.

90.Gan-Or Z, Zhou S, Ambalavanan A, Leblond CS, Xie P, Johnson A, Spiegelman D, Allen RP, Earley CJ, Desautels A, Montplaisir JY, Dion PA, Xiong L, Rouleau GA. Analysis of functional GLO1 variants in the BTBD9 locus and restless legs syndrome. Sleep Med. 2015; 16: 1151-5.

91. Fuh JL, Chung MY, Yao SC, Chen PK, Liao YC, Hsu CL, Wang PJ, Wang YF, Chen SP, Fann CS, Kao LS, Wang SJ. Susceptible genes of restless legs syndrome in migraine. Cephalalgia. 2016; 36: 1028-37.

92. Parish JM. Genetic and immunologic aspects of sleep and sleep disorders. Chest. 2013; 143: 1489-99.

93. Szentkirályi A, Völzke H, Hoffmann W, Winkelmann J, Berger K. Lack of association between genetic risk loci for restless legs syndrome and multimorbidity. Sleep. 2016; 39: 111-5.

94. Khan FH, Ahlberg CD, Chow CA, Shah DR, Koo BB. Iron, dopamine, genetics, and hormones in the pathophysiology of restless legs syndrome. $\mathrm{J}$ Neurol. 2017; 264: 1634-41.

95. Cohen J. The birth of CRISPR Inc. Science. 2017; 355: 680-4.

96. Cohen J. CRISPR patent ruling leaves license holders scrambling. Science. 2017; 355: 786. 
97. Jinek M, Chylinski K, Fonfara I, Fonfara I, Hauer M, Doudna JA, Charpentier E. A programmable dual-RNA-guided DNA endonuclease in adaptive bacterial immunity. Science. 2012; 337: 816-21.

98. Shalem O, Sanjana NE, Zhang F. High-throughput functional genomics using CRISPR-Cas9. Nat Rev Gen. 2015; 16: 299-311.

99. Lin J, Zhou Y, Liu J, Chen J, Chen W, Zhao S, Wu Z, Wu N. Progress and application of CRISPR/Cas technology in biological and biomedical investigation. J Cell Biochem. 2017; 118: 3061-71.

100. Franco-Tormo MJ, Salas-Crisostomo M, Rocha NB, Budde H, Machado S, Murillo-Rodríguez E. CRISPR/Cas9, the Powerful New Genome-Editing Tool for Putative Therapeutics in Obesity. J Mol Neurosci. 2018; 65: 10-6.

101. Murillo-Rodríguez E, Barbosa Rocha N, Barciela Veras A, Budde H, Machado S. The end of snoring?: Application of CRISPR/Cas9 genome editing for sleep disorders. Sleep and Vigilance. 2018; 2: 13-21.

102. Toth LA, Bhargava P. Animal models of sleep disorders. Comp Med. 2013; 63: 91-104.

103. Gillombardo CB, Darrah R, Dick TE. C57BL/6 J mouse apolipoprotein A2 gene is deterministic for apnea. Resp Physiol Neurobiol. 2017; 235: 8894. 


\section{Figure legends.}

Figure 1. Polysomnographic features of the sleep-wake cycle. The states of vigilance comprise: Wakefulness, slow wave sleep and rapid eye movement (REM) sleep by electroencephalogram (EEG) and electromyogram (EMG) traces. Wakefulness shows EEG patterns of rapid (alpha) activity $(8-13 \mathrm{~Hz})$ and higher activity is recorded in the EMG. The slow wave sleep state displays EEG spindle activity as well as a low voltage, including $\mathrm{K}$ complexes and waves over $100 \mu \mathrm{V}$ of amplitude and less than $2 \mathrm{~Hz}$ frequency accompanied with EMG reduced activity. REM sleep displays in the EEG, low voltage mixed frequencies $(2-7 \mathrm{~Hz})$ as well as

muscle twitches recorded in the EMG. Abbreviations: Electroencephalogram (EEG); electromyogram (EMG); rapid eye movement sleep (REMS).

Figure 2. Putative model of Hypothetical use of CRISPR/Cas9 for editing genes related to sleep disorders. By molecular manipulation of genes linked to sleep disturbances, a novel therapeutical approach might represent an efficient treatment for insomnia, OSA, narcolepsy, advanced sleep phase syndrome, restless legs syndrome or other sleep disturbances. 